\title{
Seroprevalence and risk factors of herpes simplex virus type 2 among pregnant women in Dhamar city, Yemen
}

\begin{abstract}
Herpes simplex virus type 2 is the common cause of genital ulcer disease worldwide. Genital herpes infection is a major concern in pregnancy due to the risk of neonatal transmission.

Materials and methods: A descriptive cross-sectional survey was conducted from August 2016 to March 2017 in some hospitals and health centers to assess the seroprevalence and risk factors of herpes simplex virus type 2 infection among pregnant women attending antenatal care in Dhamar city, Yemen. After taking written consent, socio-demographic, behavioral and obstetric history along with blood samples were collected from 200 pregnant women using a pre-structured questionnaire. Sera were analyzed for HSV-2 specific IgG using Electro-Chemiluminescence Immunoassay (ECLIA) method.
\end{abstract}

Results: The overall seroprevalence of HSV-2 infection was $6 \%$ (12/200) among pregnant women in Dhamar city. Levels of education and some obstetrical history such as numbers previous abortion $(\mathrm{P}=0.03)$, stillbirth $(\mathrm{P}=0.001)$. Although the study showed, there are significant differences in some symptoms, such as itching $(\mathrm{P}=0.02)$ and inflammation during urination $(\mathrm{P}=0.03)$.

Conclusion: Overall, the seroprevalence of HSV-2 infection among pregnant women in Dhamar city is low. There is a critical need to adopt screening of HSV-2 into the antenatal profile tests. There is also need for more health education of this virus infection, methods of transmission, associated risk factors, and effective prevention and control strategies.

Keywords: seroprevalence, risk-factors, hsv-2, pregnant women, eclia, Dhamar, Yemen
Volume 6 Issue 3 - 202 I

\author{
Mohammed NQ Al-Bana,' Qais YM \\ Abdullah,' Saad Al-Arnoot,' Abdul-Rahman \\ Homid,' Rua'a MY Alsayaghi, ${ }^{2}$ Mofeed Al- \\ Nowihi,' Assem Al-Thobahni' \\ 'Biology Department, Faculty of Science, Sana'a University, \\ Sana'a, Yemen \\ 2Microbiology Department, Faculty of Medicine and Health \\ Sciences, Sana’a University, Sana'a, Yemen
}

\begin{abstract}
Correspondence: Saad Al-Arnoot, Microbiology Branch, Department of Biology, Faculty of Science, Sana'a University, Sana'a, Yemen, Tel 00967774667900 ,
\end{abstract}

Email saad.alarnoot@gmail.com

Received: June 26, 2021 | Published: July 05, 2021

\section{Introduction}

Herpes simplex virus (HSV) is an enveloped, double stranded DNA virus, belonging to Herpesviridae family ${ }^{1}$ Genital herpes may be caused by either HSV-1 or HSV-2 but the majority of cases worldwide are caused by HSV-2. ${ }^{2} \mathrm{HSV}-2$ is a pathogen sexually transmitted and causes a severe chronic infection at both the symptomatic and asymptomatic periods. ${ }^{3}$ It is the worldwide natural cause of genital ulcers. ${ }^{4}$

In women, transmitted through mucus membranes and intact skin, who migrate to the nerve tissues, where they remain in a state of latentity, the group of pregnant women is important since they are ready to infect their partner. HSV-1 dominates in orofacial lesions and is typically found in trigeminal ganglia while lumbosacral ganglia are the most often associated with HSV-2.,

HSV-2 is almost sexually transmitted and is the common cause of genital ulcer disease worldwide. ${ }^{6}$ Genital ulcer infection causes during pregnancy which has been a problem of neonatal herpes, a severe condition because of the high mortality and long-term neurological sequelae noted in about $20 \%$ of survivors. ${ }^{7}$

HSV disease of the newborn can be acquired during one of the three-time periods; in utero, prenatally, or postnatally. The most common mode of transmission is via direct contact of the baby with infected vaginal secretions during delivery. ${ }^{8}$ Pregnant women then become a target for surveillance of the infection to avoid the risk of neonatal transmission. Seroprevalence studies showed wide variations in infection rates by geographic location..$^{911}$ This study aimed to assess the seroprevalence of HSV-2, and associated risk factors among pregnant women in Dhamar city, Yemen.

\section{Materials and methods}

\section{Study area and population}

This is a cross-sectional descriptive study conducted in Dhamar city.It is situated in northern Yemen, about $100 \mathrm{~km} 2$ away from Yemen's capital. In terms of population, Dhamar is Yemen's six largest cities. The population of the Republic of Yemen was $1,330,108$, according to the last population census in 2004 , and $6.8 \%$. The percentage is estimated to be from 660,553 to 669,555 of men to women. ${ }^{12}$ Nevertheless, the population may change as a result of the civil war, due to emigration to or from Dhamar.

\section{Data collection}

In order to collect information about sociodemographic properties, reproductive and obstetric features, clinical symptoms and riskrelated data, the questionnaire was developed. It was planned to coincide with this study, following several previous studies, ${ }^{13,14}$ with slight modifications. The questionnaire was first created in English and translated into Arabic to help researchers complete the survey in some cases. Many were "yes or no" questions and it took about 5 minutes to complete the questionnaire. 


\section{Sample collection, handling and storage}

After having received written and verbal permission from the participants, each consenting subject has been taken by venipuncture from a blood sample (five $\mathrm{ml}$ ) which was then transferred to a nonantiagulating bottle and may coagulate. Then it centrifuged and the serum was moved to cryovials ( $3000 \mathrm{rpm}, 5 \mathrm{~min}$ ). The serum obtained from each study subject has been put in two different tubes of Eppendorf. The initial sample was one and the second was the backup sample. It was done to prevent prolonged freeze / thaw (reduced) or incomplete serum cycles.

The second sample was used as a backup sample if something was incorrect or the quantity was insufficient. At -10 to $-20{ }^{\circ} \mathrm{C}$, serum samples were stored. These samples were saved in two separate locations at various freezers and checked daily in case of power failure, with emergency power supply. Once in the morning and once in the afternoon, samples were taken once in the freezer for the first serologic test and placed overnight in a refrigerator at $4{ }^{\circ} \mathrm{C}$. The samples were removed earlies in the morning from the refrigerator for serologic tests after thawing in the refrigerator overnight.

\section{Serologic testing}

Serological assays were performed by using ECLIA on the Cobas e411 system (Roach Diagnostic GmbH, Mannheim, Germany). Two hundred microliter of serum was pipetted from each Eppendorf tubes and placed in the reaction cell (sample well) of ECLIA. A new sterile disposable pipette tip was used for each serum sample. The study number (SNO) on the Eppendorf tubes was cross-checked with the SNO entered into the Cobas e411 system to ensure that there were no numbering errors of samples. All samples equal to or above the index of $\geq 1.0 \mathrm{COI}$ were considered positive. The entire samples were interpreted as negative with $<0.51 \mathrm{COI}$ index and the samples were equivocal with a $0.51-<1.0 \mathrm{COI}$ index.

\section{Ethical consideration}

This research was ethically carried out following the corresponding procedure by the Biology Department of the Faculty of Sciences of the Ethics Committee of the University of Sana'a. Before taking the sample, all women were explained in the questionnaire for this study. The use of numbers instead of names ensured confidentiality. The study was also obtained oral and written consent.

\section{Results}

The present study conducted on a total of 200 pregnant women at antenatal clinics in some hospitals and health centers in Dhamar city during the period from August 2016 to March 2017. This section describes the results of the overall prevalence of HSV-2 IgG antibody among pregnant women, distribution of HSV-2 IgG antibody among respondents with a socio-demographic view, obstetrical history, risk factor and clinical characteristic for HSV-2 IgG antibody.

\section{Socio-demographic characteristics of pregnant women:}

A total of 200 pregnant women were enrolled in the study. The age of pregnant women ranged from 16 to 40 years. The mean (SD) age of the pregnant women was 25.5 (5.7) years. One Hundred fifty-nine $(80.30 \%)$ of these women were born in Dhamar Governorate and 41 $(19.7 \%)$ were born in other regions12 $(6.0 \%)$ in Sana'a, $12(6.0 \%)$ in Taiz, 8 (4.0\%) in Al-baida, $3(1.5 \%)$ in Ibb, 2(1.0\%) in Amran, 1 $(0.5 \%)$ in Hodeidah and $3(1.5 \%)$ unknown). More than half of the pregnant women, $102(51.0 \%)$ were living in urban or semi-urban areas. From the studied pregnant women, 78 (39\%), were illiterate, while only 44 (22\%) were in the basic educational level. Other women distributed in primary, secondary, and university 26 (13\%), 45 (22.5), and 7 (3.5\%), respectively. According to the socio-economic status, most of the studied subjects $156(78 \%)$ were at the medium economic level, while only $16(8 \%)$ were at a relatively high economic level. Most of these women, 196 (98.0\%) were housewives (Table 1).

Table I Overview of socio-demographic variables of studied pregnant women in Dhamar city $(n=200)$

\begin{tabular}{|c|c|c|}
\hline \multirow{2}{*}{ Variable } & \multicolumn{2}{|c|}{ Participants } \\
\hline & No & (\%) \\
\hline \multicolumn{3}{|l|}{ Age } \\
\hline$<20$ & 51 & 25.50 \\
\hline $21-30$ & 111 & 55.50 \\
\hline $31-40$ & 38 & 19.0 \\
\hline \multicolumn{3}{|l|}{ Marriage } \\
\hline First & 184 & 92.0 \\
\hline Second or more & 16 & 8.0 \\
\hline \multicolumn{3}{|l|}{ Marriage type } \\
\hline Monogamous & 176 & 88.0 \\
\hline Polygamous & 24 & 12.0 \\
\hline \multicolumn{3}{|l|}{ Residence } \\
\hline Rural & 98 & 49.0 \\
\hline Urban & 102 & 51.0 \\
\hline \multicolumn{3}{|l|}{ Place of birth } \\
\hline Dhamar & 159 & 80.30 \\
\hline Other & 41 & 19.70 \\
\hline \multicolumn{3}{|c|}{ Educational level } \\
\hline Illiterate & 78 & 39.0 \\
\hline Basic & 44 & 22.0 \\
\hline Primary & 26 & 13.0 \\
\hline Secondary & 45 & 22.50 \\
\hline University & 7 & 3.50 \\
\hline \multicolumn{3}{|l|}{ Occupation } \\
\hline Housewife & 196 & 98.0 \\
\hline Employee & 4 & 2.0 \\
\hline \multicolumn{3}{|c|}{ Socio-economic level } \\
\hline High & 16 & 8.0 \\
\hline Medium & 156 & 78.0 \\
\hline Low & 28 & 14.0 \\
\hline
\end{tabular}




\section{Overall prevalence of HSV-2 IgG antibodies:}

Analysis of the results showed 6\% (12 of 200) pregnant women were positive for the HSV-2 IgG antibodies, while $94 \%$ (188 of 200) cases were negative (Figure 1).

= Negative = Positive

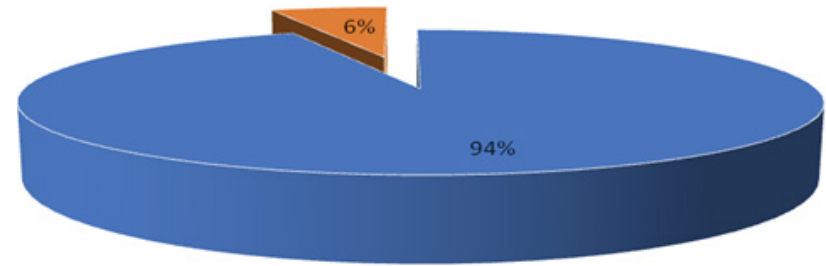

Figure I Seroprevalence of HSV-2-specific $\lg \mathrm{G}$ antibodies among pregnant women in Dhamar city $(n=200)$.

Distribution of HSV-2 IgG antibodies according to the socio-demographic characteristics:

Socio-demographic characteristics such as age, marriage and marriage type, place of birth, residence, education level, occupation, and socio-economic level. From all the socio-demographic characteristic there was only a statistically significant association between education level and seropositivity of HSV-2 IgG antibody $(\mathrm{P}=0.02)$.

\section{Distribution of HSV-2 specific IgG antibodies according to the reproductive characteristics:}

Reproductive characteristics, such as the trimester, number of term deliveries, preterm delivery, live births, stillbirths, spontaneous abortions, surviving children, cesarean-section, and malformed children were studied. The means (SD; Minimum, Maximum) of trimester, term deliveries, stillbirths, abortions, preterm birth, live births, surviving children, and malformed children were 4.75(2.60; $1.0,9.0), 2.62(2.33 ; 0.0,11.0), 0.15(0.49 ; 0.0,4.0), 0.66(1.03 ; 0.0$, 5.0), $0.16(0.52 ; 0.0,4.0), 1.51(1.69 ; 0.0,8.0), 1.47(1.65 ; 0.0,7.0)$, respectively; $74(37.0 \%), 23(11.50 \%)$, and $4(2.0 \%)$ of the pregnant women who had a history of spontaneous abortion, stillbirth, preterm birth, and malformed children, respectively. Table (3) showed that more than a third of the pregnant women $(39.50 \%)$ were in their second trimester. There was a statically significant association between seropositivity of HSV-2 IgG antibody and abortion $(\chi 2=4.50 ; \mathrm{P}=$ $0.03)$ and stillbirth $(\chi 2=11.41 ; \mathrm{P}=0.001)$. While other reproductive characteristics show no statistically significant association between seropositivity of HSV-2 IgG antibodies $(\mathrm{P}>0.05)$.

Table 2 Seroprevalence of HSV-2 specific lgG antibodies according to the socio-demographic characteristics

\begin{tabular}{|c|c|c|c|c|c|}
\hline \multirow{2}{*}{ Variable } & \multicolumn{2}{|c|}{ Participants } & \multicolumn{2}{|c|}{ IgG Positive } & \multirow{2}{*}{ p. value } \\
\hline & No & (\%) & No & (\%) & \\
\hline \multicolumn{6}{|l|}{ Age } \\
\hline$<20$ & 51 & $(25.50)$ & 2 & 3.92 & \multirow{3}{*}{0.39} \\
\hline $21-30$ & III & $(55.50)$ & 6 & 5.41 & \\
\hline $31-40$ & 38 & $(19.0)$ & 4 & 10.53 & \\
\hline \multicolumn{6}{|l|}{ Residence } \\
\hline Rural & 98 & $(49.0)$ & 9 & 9.18 & \multirow{2}{*}{0.06} \\
\hline Urban & 102 & $(51.0)$ & 3 & 2.94 & \\
\hline \multicolumn{6}{|l|}{ Educational level } \\
\hline Illiterate & 78 & $(39.0)$ & 1 & $(1.28)$ & \multirow{5}{*}{0.02} \\
\hline Basic & 44 & $(22.0)$ & 7 & $(15.91)$ & \\
\hline Primary & 26 & $(13.0)$ & 1 & $(3.85)$ & \\
\hline Secondary & 45 & $(22.50)$ & 3 & $(6.67)$ & \\
\hline University & 7 & $(3.50)$ & 0 & $(0.0)$ & \\
\hline \multicolumn{6}{|l|}{ Occupation } \\
\hline Housewife & 196 & $(98.0)$ & 12 & $(6.12)$ & \multirow{2}{*}{0.60} \\
\hline Employee & 4 & $(2.0)$ & 0 & $(0.0)$ & \\
\hline \multicolumn{6}{|c|}{ level of household income } \\
\hline High & 16 & $(8.0)$ & 0 & $(0.0)$ & \multirow[t]{3}{*}{0.34} \\
\hline Middle income. & 156 & $(78.0)$ & 9 & $(5.77)$ & \\
\hline Low & 28 & $(14.0)$ & 3 & $(10.7 I)$ & \\
\hline \multicolumn{6}{|l|}{ Place of birth } \\
\hline Dhamar & 159 & $(80.30)$ & 11 & 6.92 & \multirow{2}{*}{0.40} \\
\hline Other & 41 & (19.70) & I & 2.4 & \\
\hline
\end{tabular}


Table 3 Seroprevalence of HSV-2 specific IgG antibodies according to the reproductive characteristics

\begin{tabular}{|c|c|c|c|c|c|c|c|c|}
\hline \multirow{2}{*}{ Variable } & \multicolumn{2}{|c|}{ Participants } & \multicolumn{2}{|c|}{ IgG Positive } & \multicolumn{2}{|c|}{ IgG Negative } & \multirow{2}{*}{$\chi 2$} & \multirow{2}{*}{ P-value } \\
\hline & No & (\%) & No & (\%) & No & (\%) & & \\
\hline \multicolumn{9}{|l|}{ Trimester } \\
\hline First & 67 & $(33.50)$ & 5 & (7.46) & 62 & $(92.54)$ & 0.77 & 0.67 \\
\hline Second & 79 & $(39.50)$ & 5 & $(6.33)$ & 74 & $(93.67)$ & & \\
\hline Third & 54 & $(27)$ & 2 & $(3.70)$ & 52 & $(96.30)$ & & \\
\hline \multicolumn{9}{|l|}{ Term of pregnancy } \\
\hline First & 47 & $(23.50)$ & 3 & $(6.38)$ & 44 & $(93.62)$ & 0.01 & 0.89 \\
\hline Second or more & 153 & $(76.50)$ & 9 & $(5.88)$ & 144 & $(94.12)$ & & \\
\hline \multicolumn{9}{|l|}{ Preterm birth } \\
\hline Yes & 23 & $(4 I .0)$ & 3 & (l.35) & 20 & $(86.96)$ & 2.28 & 0.13 \\
\hline No & 177 & $(54.0)$ & 9 & (8.73) & 168 & $(94.92)$ & & \\
\hline \multicolumn{9}{|l|}{ Cesarean-section } \\
\hline Yes & 16 & $(8.0)$ & 1 & $(6.25)$ & 15 & $(93.75)$ & 0.001 & 0.96 \\
\hline No & 184 & $(92.0)$ & $\mathrm{II}$ & $(5.98)$ & 173 & $(94.02)$ & & \\
\hline \multicolumn{9}{|l|}{ Abortion } \\
\hline Yes & 74 & $(37.0)$ & I & (I.35) & 73 & $(98.65)$ & 4.5 & $0.03^{*}$ \\
\hline No & 126 & $(63.0)$ & 11 & (8.73) & 115 & $(91.27)$ & & \\
\hline \multicolumn{9}{|l|}{ Stillbirth child } \\
\hline Yes & 23 & $(I I .50)$ & 5 & $(21.74)$ & 18 & $(78.26)$ & $11.4 \mid$ & $0.00 I^{*}$ \\
\hline No & 177 & $(88.50)$ & 7 & $(3.95)$ & 170 & $(96.05)$ & & \\
\hline \multicolumn{9}{|l|}{ Live births } \\
\hline None & 82 & $(41.0)$ & 4 & $(4.88)$ & 78 & $(95.12)$ & 1.2006 & 0.54 \\
\hline OI-Apr & 108 & $(54.0)$ & 8 & $(7.4 I)$ & 100 & $(92.59)$ & & \\
\hline$>4$ & 10 & $(5.0)$ & 0 & $(0.0)$ & 10 & $(100)$ & & \\
\hline \multicolumn{9}{|l|}{ Surviving children } \\
\hline None & 85 & $(42.5)$ & 4 & $(4.7 I)$ & 81 & $(95.29)$ & 1.2768 & 0.52 \\
\hline OI-Apr & 106 & $(53.0)$ & 8 & (7.55) & 98 & $(92.45)$ & & \\
\hline$>4$ & 9 & $(4.5)$ & 0 & $(0.0)$ & 9 & $(100.0)$ & & \\
\hline \multicolumn{9}{|c|}{ Malformed children } \\
\hline Yes & 4 & $(2.0)$ & 0 & $(0.0)$ & 4 & $(100)$ & 0.26 & 0.6 \\
\hline No & 196 & $(98.0)$ & 12 & $(6.12)$ & 184 & $(93.88)$ & & \\
\hline
\end{tabular}

\section{Distribution of HSV-2 antibodies according to the} symptoms characteristics:

Symptoms, such as fever, headaches, itching, tingling, inflammation during urination, swelling and blisters, were studied (Table 4). 96 (48.0\%), 104 (52.0\%), 86 (43.0\%), 92 (46.0\%), 125 (62.50\%), 19 $(9.50 \%)$ and $39(19.50 \%)$, of the pregnant women had a symptoms of fever, headaches, itching, tingling, inflammation during urination, swelling and blisters respectively. There was a statistically significant association between the itching $(\chi 2=5.33 ; \mathrm{P}=0.02)$ and inflammation during urination $(\chi 2=4.63 ; \mathrm{P}=0.03)$ seropositivity of HSV-2 $\operatorname{IgG}$ antibody. While other symptom characteristics did not show any statistically significant association between seropositivity of HSV-2 IgG antibodies $(\mathrm{P}>0.05)$ 
Table 4 Seroprevalence of HSV-2-specific IgG antibodies according to symptoms

\begin{tabular}{|c|c|c|c|c|c|c|c|c|}
\hline \multirow{2}{*}{ Variable } & \multicolumn{3}{|c|}{ Participants } & \multicolumn{2}{|c|}{ IgG Positive } & \multirow{2}{*}{$\begin{array}{l}\text { IgG Negative } \\
\text { (\%) }\end{array}$} & \multirow{2}{*}{$\chi^{2}$} & \multirow{2}{*}{ P-value } \\
\hline & No & (\%) & No & (\%) & No & & & \\
\hline \multicolumn{9}{|l|}{ Fever } \\
\hline Yes & 96 & $(48.0)$ & 5 & $(5.21)$ & 91 & $(94.79)$ & \multirow{2}{*}{0.2} & \multirow{2}{*}{0.65} \\
\hline No & 104 & $(52.0)$ & 7 & $(6.73)$ & 97 & $(93.27)$ & & \\
\hline \multicolumn{9}{|c|}{ Headaches } \\
\hline Yes & 104 & $(52.0)$ & 9 & $(8.65)$ & 95 & (91.35) & \multirow{2}{*}{2.7} & \multirow{2}{*}{0.09} \\
\hline No & 96 & $(48.0)$ & 3 & $(3.13)$ & 93 & $(96.88)$ & & \\
\hline \multicolumn{9}{|l|}{ Itching } \\
\hline Yes & 86 & $(43.0)$ & 9 & $(10.47)$ & 77 & $(89.53)$ & \multirow{2}{*}{5.33} & \multirow{2}{*}{$0.02 *$} \\
\hline No & 114 & -57 & 3 & $(2.63)$ & 111 & $(97.37)$ & & \\
\hline \multicolumn{9}{|l|}{ Tingling } \\
\hline Yes & 92 & $(46.0)$ & 7 & $(7.61)$ & 85 & $(92.39)$ & \multirow{2}{*}{0.78} & \multirow{2}{*}{0.37} \\
\hline No & 108 & $(54.0)$ & 5 & $(4.63)$ & 103 & $(95.37)$ & & \\
\hline \multicolumn{9}{|c|}{ Inflammation during urination } \\
\hline Yes & 125 & $(62.50)$ & 11 & $(8.8)$ & 114 & $(91.20)$ & \multirow{2}{*}{4.63} & \multirow{2}{*}{$0.03 *$} \\
\hline No & 75 & $(37.50)$ & I & $(1.33)$ & 74 & $(98.67)$ & & \\
\hline \multicolumn{9}{|l|}{ Swelling } \\
\hline Yes & 19 & $(9.50)$ & 0 & $(0.0)$ & 19 & $(100.0)$ & \multirow{2}{*}{1.34} & \multirow{2}{*}{0.24} \\
\hline No & 181 & $(90.50)$ & 12 & $(6.63)$ & 169 & $(93.37)$ & & \\
\hline \multicolumn{9}{|l|}{ Blisters } \\
\hline Yes & 39 & $(19.50)$ & 2 & $(5.13)$ & 37 & $(94.87)$ & \multirow{3}{*}{0.06} & \multirow{3}{*}{0.79} \\
\hline No & 161 & $(80.50)$ & 10 & $(6.21)$ & $|5|$ & $(93.79)$ & & \\
\hline Total & 200 & $(100)$ & 12 & $(6.0)$ & 188 & $(94.0)$ & & \\
\hline
\end{tabular}

\section{Discussion}

From our investigation, there is no previous community-based seroepidemiological study investigating HSV-2 IgG antibodies among pregnant women in Dhamar city, Yemen. Hence, we focus on concerning the prevalence of HSV-2 IgG antibodies among pregnant women in Dhamar city. The study also assessed some associated risk factors that increase the infection rate among pregnant women. It would provide not only current information on the numbers of pregnant women at risk of these viral infections but also provide some useful information for health planners, care providers and health promotion activities.

The percentage of HSV-2 IgG observed in this study was (6.0\%). similar to the previous study in other different countries such as Saudi Arabia 5.5\%, 6.5\%, 6.8\%, ${ }^{15-17}$ Iraq $9 \%,{ }^{18}$ Sudan $7.6 \%,{ }^{11}$ Turkey $4.4 \%$ , 5\%, ${ }^{19-20}$ India $8.7 \%, 6.7 \%,{ }^{21,22}$ Kashmir 7.5\%, ${ }^{23}$ Bangladesh $9.91 \% .{ }^{24}$ Their previous studies showed similar findings in terms of the rate of HSV-2 IgG infection. This similarity in their studies may be related to one geographical location in (Middle East) where the culture is close in these countries. In addition, a slightly lower percentage of maternal immunity from our study was reported by researchers in Iraq $2.2 \% .{ }^{25}$

Regarding the high level of HSV-2 IgG, seropositivity was reported also by other countries researchers such as in Saudi Arabia 27.1\% (9), Sudan $34.6 \%, 63.3 \%, 91.1 \% .{ }^{26}$ Iraq $22.2 \%,{ }^{27}$ Syria $52 \%,{ }^{28}$ India
$64.9 \%, 34.86 \%,{ }^{29}$ Ethiopia $32.1 \%,{ }^{30}$ Nigeria $82.2 \%, 33.3 \%,{ }^{13,31}$ Ghana $78.3 \%{ }^{32}$ Zimbabwe $49.1 \%, 51.10 \%,{ }^{33,34}$ Eastern Nepal $35.8 \%,{ }^{35}$ Cote D'ivoire 96.5\%, ${ }^{36}$ Germany $82 \%,{ }^{37}$ Switzerland $21.2 \%,{ }^{38}$ Brazil $15.6 \%{ }^{39}$ and USA $22 \% .^{10}$ These shades as mentioned above showed higher findings in terms of the rate of HSV-2 IgG infection. These higher rates may be related to several reasons, such as the size of the sample and type of target category. Another effect factor as a place of study is in the rural or the urban, perhaps due to lack of knowledge and awareness about this virus. However, the main reasons for increasing the prevalence rate of virus infection. It could be due to the poverty absence of a vaccine in those regions that plays hygiene and religion. Poverty has a significant role in increasing the incidence of infection.

The analytical data have, there was no significant association observed between increasing age with seropositivity of HSV-2 IgG antibodies but increasing the seropositivity with advanced age $(\mathrm{p}=0.39)$. It must be reiterated that as the women advanced in age, the rate of exposure to risk factors increases, leading to the high prevalence observed. Aging is known to be associated with a gradual decrease in immunity. It could contribute to the high prevalence observed which is in agreement with the previous studies reported by ${ }^{14,40}$ While in India inconsistent published by. ${ }^{29}$

In our study, there was a significant association between education level and HSV-2 seropositivity. This finding similar to some 
studies. ${ }^{21,41,42}$ While other studies found increases in the infection with the level of education by (17), studies show high seroprevalence increased with education women..$^{10}$ However, ${ }^{3,14,23}$ found no significant between education level and HSV-2 seropositivity. All of other sociodemographic data were no signs with the seroprevalence of HSV-2 IgG antibodies; this result agrees with the study by. ${ }^{25}$ The seroprevalence of HSV-2 IgG was found statistically significantly associated with the occupation of the mother. ${ }^{14,17,42}$ However, ${ }^{21,23,43}$ found no significant between occupation and HSV-2 seropositivity.

Statistical analysis showed, there was a significant association observed between stillbirth with seropositivity of HSV-2 IgG antibodies $(\mathrm{P}=0.00)$. This finding similar to the study of ${ }^{44}$ They found 73 mothers with various obstetric problems like abortion, stillbirth, premature birth and intrauterine developmental retardation, reported HSV-1 positivity in $71(97.3 \% \mathrm{HSV}-2$ IgG positivity in $65(89 \%)$ and HSV-2 IgM positivity in $6(8 \%)$. None of the characteristics considered to be risk factors were a statistically significant predisposing to HSV-2 infection. ${ }^{45}$ We were reported that $5 \%$ of the women had multiple sexual partners during pregnancy. Having multiple sexual partners and being in polygamous unions increased the risk of HSV2 acquisition threefold and fourfold, respectively. Other studies also found multiple sexual partners and polygamy to be risk factors for HSV-2 seroconversion. ${ }^{46}$ Having multiple sexual partners increases the risk of one of the partners having HSV-2 and transmitting to the others. ${ }^{45}$ Some of the common clinical symptoms associated with HSV-2 infection were observed in the pregnant women in this study, included fever, headaches, itching, tingling, inflammation during urination, swelling and blisters with studies of. ${ }^{21,47}$

In this study, there were significantly associated with the risk of infection (positive for HSV-2 IgG antibody) and itching and inflammation during urination. The pregnant women made complaints mostly of delirium. Very few of these women were positively for HSV-2 infection (IgG antibody). The overall clinical picture of HSV-2 infection is very similar to that reported by other workers in some geographical areas. Related work has reported that fever was significantly associated with HSV-2 infection; ${ }^{13}$ this could arise as a result of the immune response during infection. However ${ }^{48}$ who reported a seroprevalence of $54.3 \%$ amongst fever patients. On the other hand, blisters and ulcers in the genital area were found to be statistically associated with HSV-2 infection $(\mathrm{P}<0.05)$. This finding agrees with earlier reports by ${ }^{49}$ who reported that a $40.3 \%$ prevalence infection of HSV-2 also observed a significant association between genital ulcerations with the virus infection, ${ }^{21}$ also reported a high HSV-2 seroprevalence among subjects associated with genital ulcers. Painful urination was observed to be significantly and associated with HSV-2 infection $(\mathrm{P}<0.05)$. This finding disagrees with an earlier report by, ${ }^{49}$ who found that $21 \%$ of his study population had painful urination, but there was no significant association with the infection. One study disagrees with our study reported by ${ }^{36}$ who observed seroprevalence itching (pruritus) among subjects and significantly associated with high HSV-2 infection $(\mathrm{P}<0.85)$. This finding disagrees with our study.

\section{Conclusion}

Overall, the seroprevalence of HSV-2 infection among pregnant women in Dhamar city is low. There is a critical need to adopt screening of HSV-2 into the antenatal profile tests. There is also need for more health education of this virus infection, methods of transmission, associated risk factors, and effective prevention and control strategies.

\section{Acknowledgments}

None.

\section{Conflicts of interest}

None.

\section{Funding}

None.

\section{References}

1. Gupta R, Warren T, Wald A. Genital herpes. The Lancet. 2007;370(9605):2127-2137.

2. Paz-Bailey G, Ramaswamy M, Hawkes $\mathrm{S}$, et al. Herpes simplex virus type 2: epidemiology and management options in developing countries. Postgraduate medical journal. 2008;84(992):299-306.

3. Agabi YA, Banwat EB, Mawak JD, et al. Seroprevalence of herpes simplex virus type -2 among patients attending the Sexually Transmitted Infections Clinic in Jos, Nigeria. The Journal of Infection in Developing Countries. 2010;4(9):572-575.

4. Brown ZA, Wald A, Morrow RA, et al. Effect of serologic status and cesarean delivery on transmission rates of herpes simplex virus from mother to infant. Jama. 2003;289(2):203-209.

5. Ozouaki F, Ndjoyi-Mbiguino A, Legoff J, et al. Genital shedding of herpes simplex virus type 2 in childbearing-aged and pregnant women living in Gabon. International journal of STD \& AIDS. 2006;17(2):124-127.

6. Westhoff GL, Little SE, Caughey AB. Herpes simplex virus and pregnancy: a review of the management of antenatal and peripartum herpes infections. Obstetrical \& gynecological survey. 2011;66(10):629638.

7. Kim ID, Chang HS, Hwang KJ. Herpes simplex virus 2 infection rate and necessity of screening during pregnancy: a clinical and seroepidemiologic study. Yonsei medical journal. 2012;53(2):401-407.

8. Thompson C, Whitley R. Neonatal herpes simplex virus infections: where are we now? Hot Topics in Infection and Immunity in Children VII. Springer; 2011:221-230.

9. Ghazi HO, Telmesani AM, Mahomed MF. TORCH agents in pregnant Saudi women. Medical Principles and Practice. 2002;11(4):180-182.

10. Xu F, Markowitz LE, Gottlieb SL, et al. Seroprevalence of herpes simplex virus types 1 and 2 in pregnant women in the United States. American journal of obstetrics and gynecology. 2007;196(1):43e1-43e6.

11. Fazza MAAM. Seroprevalence of Herpes Simplex Type 2 Virus among Pregnant Women Attending some Hospitals in Khartoum State: Sudan University of Science and Technology. 2016.

12. Office CCS. Statistical yeadbook. Sana'a,. 2004:84.

13. Ameh RE, Aminu M, Ella EE. Seroprevalence of HSV-2 among Women of Reproductive Age in Zaria, Kaduna State. Biology and Medicine. 2016;8(7):1

14. Egbagba J, Mordi R. Prevalence of asymptomatic genital herpes infection in women attending the antenatal clinics of the University of Port Harcourt Teaching Hospital, Port Harcourt. Nigeria Researcher. 2015;7(11):35-42.

15. Alzahrani A, Obeid O, Almulhim A, et al. Analysis of herpes simplex 1 and $2 \mathrm{IgG}$ and $\mathrm{IgM}$ antibodies in pregnant women and their neonates. Saudi J Obstet Gynaecol. 2005;5:53-57.

16. Fageeh WM. Sexually transmitted infections among patients with herpes simplex virus at King Abdulaziz University Hospital. BMC research notes. 2013;6(1):301. 
17. Obeid OE. Prevalence of herpes simplex virus types 1 and 2 and associated sociodemographic variables in pregnant women attending King Fahd Hospital of the university. Journal of family \& community medicine. 2007;14(1):3-7.

18. Mezher MN, Mejbel FA, Hussein HK. Detection of Herpes Simplex -2 Virus in Women with Spontaneous Abortion in Al-Najaf City/Iraq. Pharmaceutical Sciences and Research. 2018;10(1):110-113.

19. Dolar N, Serdaroglu S, Yilmaz G, et al. Seroprevalence of herpes simplex virus type 1 and type 2 in Turkey. Journal of the European Academy of Dermatology and Venereology. 2006;20(10):1232-1236.

20. Özdemir M, Kalem F, FEYZİŎLU B, et al. Investigation of viral pathogens during pregnancy in a city region in Turkey. AJCI. 2011;5(2):78-81.

21. Biswas D, Borkakoty B, Mahanta J, et al. Seroprevalence and risk factors of herpes simplex virus type-2 infection among pregnant women in Northeast India. BMC Infectious Diseases. 2011;11(1):325.

22. Bochner AF, Madhivanan P, Niranjankumar B, et al. The epidemiology of herpes simplex virus type-2 infection among pregnant women in rural Mysore taluk, India. Journal of sexually transmitted diseases. 2013; 2013:750415.

23. Rathore S, Jamwal A, Gupta V. Herpes simplex virus type 2: Seroprevalence in antenatal women. Indian journal of sexually transmitted diseases. 2010;31(1):11-15.

24. Nabi S, Wasey A, Haider K, et al.. Seroprevalence of TORCH antibody in pregnant women. Journal of Armed Forces Medical College, Bangladesh. 2012;8(1):35-39.

25. Hasan ARS, Al-Duliami AA, Hwaid AH, et al.. Seroprevalence of AntiHerpes Simplex Virus Type2 IgG, IgM Antibodies Among Pregnant Women in Diyala Province. Diyala Journal of Medicine. 2013;5(1):3643.

26. El-Amin EO, Elamin OE, Ahmed RA-M, Abdulla AK, Elamin SE, Elhaj HI. Sero-Prevalence of Herpes Virus Infection in Sudanese Pregnant Women. Tropical Medicine \& Surgery. 2013.

27. Al-Marzoqi AH, Kadhim RA, Aljanabi DK, Hussein HJ, Al Tae Z. Seroprevalence study of IgG and IgM antibodies to toxoplasma, rubella, cytomegalovirus, Chlamydia trachomatis and Herpes simplex II in Pregnancy women in Babylon Province. Journal of Biology, Agriculture and Healthcare. 2012;2(10):159-164.

28. Barah F. Prevalence of herpes simplex types 1 and 2, varicella zoster virus, cytomegalovirus, immunoglobulin G antibodies among female university students in Syria. Saudi medical journal. 2012;33(9):990-994.

29. Amar OAO, Bajaj HK, Gupta N, et al. Prevalence of herpes simplex virus in pregnant women from Gangetic Plain Region of Allahabad, India. Advances in Microbiology. 2015;5(06):404.

30. Anjulo AA, Abebe T, Hailemichael F, et al. Seroprevalence and risk factors of herpes simplex virus-2 among pregnant women attending antenatal care at health facilities in Wolaita zone, Ethiopia. Virology journal. 2016;13(1):43.

31. Anaedobe CG, Ajani TA. Co-infection of herpes simplex virus type 2 and HIV infections among pregnant women in Ibadan, Nigeria. Journal of global infectious diseases. 2019;11(1):19-24.

32. Agyemang-Yeboah F, Debrah O, Timmy-Donkoh E,et al. SEROprevalence of herpes simplex virus type 1 and type 2 among women attending routine Cervicare clinics in Ghana. Currt Find of Infec Dis ReDelve: RD-INF. 2019;(1):10005.

33. Kurewa NE, Mapingure MP, Munjoma MW, et al. The burden and risk factors of sexually transmitted infections and reproductive tract infections among pregnant women in Zimbabwe. BMC infectious diseases. 2010;10(1):127.
34. Munjoma MW, Kurewa EN, Mapingure MP, et al. The prevalence, incidence and risk factors of herpes simplex virus type 2 infection among pregnant Zimbabwean women followed up nine months after childbirth. BMC women's health. 2010;10(1):2.

35. Pradhan S. Epidemiological and serological profiles of TORCH infection in pregnancy. Journal of Pathology of Nepal. 2015;5(9):705-708.

36. Zaba F, Meite S, Mlan A, et al. Seroprevalence of herpes simplex virus 2 infection among pregnant women in urban health training YopougonAttie (Cote Divoire). Journal of Medical Laboratory and Diagnosis. 2015;6(3):17-21.

37. Sauerbrei A, Schmitt S, Scheper T, et al. Seroprevalence of herpes simplex virus type 1 and type 2 in Thuringia, Germany, 1999 to 2006. Eurosurveillance. 2011;16(44):20005.

38. Kucera P, Gerber S, Marques-Vidal P, et al. Seroepidemiology of herpes simplex virus type 1 and 2 in pregnant women in Switzerland: an obstetric clinic based study. European Journal of Obstetrics \& Gynecology and Reproductive Biology. 2012;160(1):13-17.

39. Caldeira TDM, Goncalves CV, Oliveira GRd, et al. Prevalence of herpes simplex virus type 2 and risk factors associated with this infection in women in southern Brazil. Revista do Instituto de Medicina Tropical de São Paulo. 2013;55(5):315-321.

40. Cusini M, Ghislanzoni M. The importance of diagnosing genital herpes. Journal of Antimicrobial Chemotherapy. 2001;47(supp1_1):9-16.

41. Aljumaili ZKM, Alsamarai AM, Najem WS. Seroprevalence of Herpes Simplex Virus Type 2 (HSV 2) in women with bad obstetric history. American Journal of Dermatology and Venereology. 2013;2(3):31-38.

42. Hassan HMM, Alsamarai AM, Aljumaili ZKM, et al. Association between Herpes Simplex virus type 2 (HSV 2) and bad obstetric outcomes. Our Dermatology Online. 2014;5(1):19.

43. Duran N, Yarkin F, Evruke C, et al. Asymptomatic herpes simplex virus type 2 (HSV-2) infection among pregnant women in Turkey. Indian Journal of Medical Research. 2004;120:106-110.

44. Cengiz L, Kiyan M, Cengiz A, et al. Detection of herpes simplex virus 1 and 2 (HSV-1 and HSV-2) IgG and IgM by ELISA in cord blood and sera of mothers with pregnancy complications. Mikrobiyoloji bulteni. 1993;27(4):299-307.

45. Nakubulwa S, Kaye DK, Bwanga F, et al. Incidence and risk factors for herpes simplex virus type 2 seroconversion among pregnant women in Uganda: A prospective study. The Journal of Infection in Developing Countries. 2016;10(10):1108-1115.

46. Anzivino E, Fioriti D, Mischitelli M, et al. Herpes simplex virus infection in pregnancy and in neonate: status of art of epidemiology, diagnosis, therapy and prevention. Virology journal. 2009;6(1):40.

47. Apurba S, Sandhya B, Senthamarai S, et al. Serological evaluation of herpes simplex virus Type-1/Type-2 infections in pregnant women with bad obstetric history in a tertiary care hospital, Kanchipuram. International Journal of Advanced Research. 2013;1(3):123-128.

48. Aminu M, Bodam B, Adams A, Sero-prevalence of herpes simplex virus type 2 among pregnant women and patients presenting with fever at the University Health Services of Ahmadu Bello University Zaria, Nigeria. An oral paper presented at the 49th Annual Conference of the Science Association of Nigeria held at University of Ilorin, Nigeria. 2014.

49. Tobian AA, Grabowski MK, Serwadda D, et al. Reactivation of herpes simplex virus type 2 after initiation of antiretroviral therapy. The Journal of infectious disease. 2013;208(5):839-846. 